\title{
Increasing accuracy: The advantage of using open access species occurrence database in the Red List assessment
}

\author{
IYAN ROBIANSYAH ${ }^{1,3, \boldsymbol{}}$, WITA WARDANI ${ }^{2,3}$ \\ ${ }^{1}$ Research Center for Plant Conservation and Botanic Gardens, Indonesian Institute of Sciences. J1. Ir. H. Juanda 13, Bogor 16122, West Java, Indonesia. \\ Tel./fax.: +62-251-8322187, `email: iyan.robiansyah@lipi.go.id. \\ ${ }^{2}$ Research Center for Biology, Indonesian Institute of Sciences. Jl. Raya Bogor Km. 46, Cibinong, Bogor 16911, West Java, Indonesia \\ ${ }^{3}$ Indonesian Plant Red List Authority. J1. Raya Bogor Km. 46, Cibinong, Bogor 16911, West Java, Indonesia
}

Manuscript received: 27 April 2020. Revision accepted: 21 July 2020.

\begin{abstract}
Robiansyah I, Wardani W. 2020. Increasing accuracy: The advantage of using open access species occurrence database in the Red List assessment. Biodiversitas 21: 3658-3664. IUCN Red List is the most widely used instrument to assess and advise the extinction risk of a species. One of the criteria used in IUCN Red List is geographical range of the species assessed (criterion B) in the form of extent of occurrence (EOO) and/or area of occupancy (AOO). While this criterion is presumed to be the easiest to be completed as it is based mainly on species occurrence data, there are some assessments that failed to maximize freely available databases. Here, we reassessed the conservation status of Cibotium arachnoideum, a tree fern distributed in Sumatra and Borneo. This species was previously assessed by Praptosuwiryo (2020, Biodiversitas 21 (4): 1379-1384) which classified the species as Endangered (EN) under criteria B2ab(i,ii,iii); C2a(ii). Using additional data from herbarium specimens recorded in the Global Biodiversity Information Facility (GBIF) website and from peer-reviewed scientific papers, in the present paper we show that $C$. arachnoideum has a larger extent of occurrence (EOO) and area of occupancy (AOO), more locations and different conservation status compared to those in Praptosuwiryo (2020). Our results are supported by the predicted suitable habitat map of $C$. arachnoideum produced by MaxEnt modelling method. Based on our assessment, we propose the category of Vulnerable (VU) C2a(i) as the global conservation status for C. arachnoideum. Our study implies the advantage of using open access databases to increase the accuracy of extinction risk assessment under the IUCN Red List criteria in regions like Indonesia, where adequate taxonomical information is not always readily available.
\end{abstract}

Keywords: AOO, Cibotium arachnoideum, GBIF, IUCN Red List, MaxEnt, threatened plant

\section{INTRODUCTION}

IUCN Red List is the most widely used instrument to assess and advise the extinction risk of a species. To date, the IUCN Red List has assessed the extinction risk of 116,177 species across several major taxonomic groups, including Fungi (285 species), Plantae (40,468 species), Animalia (75,409 species) and Chromista (15 species) (IUCN 2020). Rodrigues et al. (2006) argued that the following values lead to the increasing recognition and use of the IUCN Red List: i) based on objective criteria; ii) rich in supporting data on distribution, population size and decline, threats, habitat preferences and use, among others; iii) applied to wider extent geographically, taxonomically and ecologically; and iv) consistency in its methodology and therefore becoming a global standard. Due to these values, the IUCN Red List has become a powerful tool for conservation assessment and the most comprehensive and scientifically accurate information resource about the extinction risk of species.

To assess the conservation status of a species, the IUCN Red List provides a set of criteria and sub-criteria. There are five criteria (A-E) in the assessment, namely population size reduction (criterion $\mathrm{A}$ ), geographical range (criterion $\mathrm{B})$ in the form of extent of occurrence (EOO) and/or area of occupancy (AOO), small population size and decline (criterion $\mathrm{C}$ ), very small or restricted population (criterion
D), and quantitative analysis (criterion E) (IUCN 2012). Each criterion has additional sub-criteria and threshold values that have to be met in order to complete a full Red List assessment.

In terms of data requirement, criterion B is presumed to be the easiest to be completed as it is based mainly on species occurrence data. This can be obtained from herbarium records, databases, and published scientific papers which in most cases are found as the best available evidence to perform an assessment. However, when assessing the conservation status of a species, two out of three additional sub-criteria have to be fulfilled under this criterion, i.e. i) severely fragmented or number of locations, ii) continuous decline in any of EOO, AOO, area, extent and/or quality of habitat, number of locations or subpopulations, or number of mature individuals, and iii) extreme fluctuations in any of EOO, AOO, number of locations or subpopulations, and number of mature individuals (IUCN 2012).

While considered as the easiest criterion to fulfill, there are some assessments that failed to maximize the freely available resources. For example, in a recently published paper, Praptosuwiryo (2020, Biodiversitas 21 (4): 13791384) (hereinafter referred to as Praptosuwiryo (2020)) conducted a conservation status assessment for Cibotium arachnoideum (C. Chr.) Holttum, a tree fern species distributed in Sumatra and Borneo. The assessment was 
based on ten herbarium specimen records deposited at Herbarium Bogoriense (BO). Population size data from North Sumatra (Praptosuwiryo et al. 2011) and Bengkulu (Praptosuwiryo and Wardani 2008) were also used, in which the number of mature individuals was estimated to be 327 and 19, respectively for both locations. Using Geospatial Conservation Assessment Tool (GeoCAT; Bachman et al. 2011), Praptosuwiryo (2020) estimated that the respected EOO and AOO of the species were $875,948.11 \mathrm{~km}^{2}$ and $44 \mathrm{~km}^{2}$. Based on these data, Praptosuwiryo (2020) assigned the category of Endangered (EN) for $C$. arachnoideum under the criteria of $\mathrm{B} 2 \mathrm{ab}(\mathrm{i}, \mathrm{ii}, \mathrm{iii}) ; \mathrm{C} 2 \mathrm{a}$ (ii), i.e. $\mathrm{AOO}<500 \mathrm{~km} 2$ (criterion B2), severely fragmented or number of locations less than five (sub-criterion a), continuing decline in extent of occurrence, area of occupancy and area, extent and/or quality of habitat (sub-criterion $\mathrm{b}(\mathrm{i}, \mathrm{ii}, \mathrm{iii})$ ), continuing decline in any rate (C2), and $95-100 \%$ of mature individuals in one subpopulation (sub-criterion a(ii)).

While we appreciate the aim of the study by Praptosuwiryo (2020), we argue that there were several caveats in the methodological works including the limited number of occurrence records used, incomplete understanding on the IUCN Red List criteria and the definition of its key terms and concepts, and flawed assumption on the population size calculation of $C$. arachnoideum. All these factors led the author to incorrectly assigned the extinction risk category to the species.

Using additional data from herbarium specimens recorded in an open-access species occurrence database and published scientific papers, in this paper, we aimed to reassess the conservation status of $C$. arachnoideum and compare it with that of the Praptosuwiryo (2020). To strengthen our assessment, a suitability habitat map of the species was produced using species distribution modelling (SDM). We expected that this study can provide a broader understanding on the advantage of using open access databases to increase the accuracy of extinction risk assessment under the IUCN Red List criteria.

\section{MATERIALS AND METHODS}

\section{Occurrence records}

Occurrences data of Cibotium arachnoideum was extracted from herbarium records stored in the Global Biodiversity Information Facility (GBIF) website (GBIF.org 2020a) as well as from peer-reviewed scientific papers (i.e. Jaman et al. 1999; Praptosuwiryo et al. 2011; Praptosuwiryo 2020). We ensured the confidence level of GBIF records by tracing each of them back to the source. After manual data cleaning, a total of 41 occurrence records were successfully collected, comprising 4 records from Sumatra, 9 records from North Kalimantan, 7 records from Sarawak and 21 records from Sabah (Table 1). Within these records, Praptosuwiryo (2020) only used 12 records to complete the assessment.

\section{Calculation of extent of occurrence (EOO) and area of occupancy (AOO)}

There are two types of geographical range that are used in the IUCN Red List under criterion B: EOO (criterion B1) and AOO (criterion B2). Definitions of and methods used to calculate EOO and AOO are detailed in IUCN Standards and Petitions Committee (2019). Similar to the methods by Praptosuwiryo (2020), the EOO and AOO of C. arachnoideum in our study were calculated using GeoCAT based on the collected occurrence records (Bachman et al. 2011). The tool is freely available on http:/geocat.kew.org/. As the information on the number of locations is required under criterion $\mathrm{B}$, it was also estimated during GeoCAT analysis. In the Red List assessment, location is defined as "a geographically or ecologically distinct area in which a single threatening event can rapidly affect all individuals of the taxon present" (IUCN Standards and Petitions Committee 2019).

\section{Species distribution modelling for Cibotium arachnoideum}

To strengthen our analysis, a habitat suitability map of C. arachnoideum was produced using Maximum Entropy (MaxEnt) method (Phillips et al. 2006). MaxEnt is one of the most robust modelling methods using presence-only data (Elith et al. 2006, 2011; Pearson et al. 2007; Wisz et al. 2008; Kumar and Stohlgren 2009). For modelling inputs, we used 41 occurrence records obtained from the present study as well as nineteen bioclimatic variables for the current period (Bio1-Bio19, Hijmans et al. 2005), land cover and elevation layers that were retrieved from the WorldClim website (https://www.worldclim.org/), Broxton et al. (2014) and The Shuttle Radar Topography Mission (SRTM) global elevation data (http://srtm.csi.cgiar.org/), respectively. In addition, slope and aspect were also used in the modelling and were derived from elevation data using surface analysis extension in ArcMap 10.1. All these 23 environmental variables (Table 2) were in 30 arc-seconds (approximately $1 \mathrm{~km}^{2}$ ) resolution and were cropped to Sumatra, Kalimantan, Malaysia and Brunei Darussalam political boundaries.

Prior to running the Maxent model, the software was set to the following settings: created response curves, did the jackknife to measure variable importance, logistic output format, ASCII output file type and the auto feature. To increase model accuracy and minimize model uncertainty, we used 20-fold cross-validation replicated run type. Model accuracy was evaluated using area under the curve (AUC) of the receiver operating characteristic (ROC), a thresholdindependent index that effectively evaluates model ability to discriminate presence from absence (Wei et al. 2018). The AUC value ranges from 0 (random prediction) to 1 (perfect prediction). The map resulted from the modelling process was converted into suitable and unsuitable areas using maximum test sensitivity plus specificity logistic threshold (Liu et al. 2016; Brites-Neto and Duarte 2015). 
Table 1. Occurrence data of Cibotium arachnoideum extracted from peer-reviewed scientific papers and preserved specimen records stored in the Global Biodiversity Information Facility (GBIF) website (GBIF.org 2020a). Records used by Praptosuwiryo (2020) are grey-highlighted

\begin{tabular}{|c|c|c|c|c|c|}
\hline Locality & Country & $\begin{array}{l}\text { Elevation } \\
(\mathbf{m} \text { asl })\end{array}$ & $\begin{array}{l}\text { Collection } \\
\text { date }\end{array}$ & $\begin{array}{l}\text { Record } \\
\text { number }\end{array}$ & Basis of record \\
\hline West Sumatra: Gunung Sago & Indonesia & 2000 & 26/07/1918 & 4019 & Preserved specimen \\
\hline Lampung: Gunung Rajabasa & Indonesia & - & 1857 & s.n. & Preserved specimen \\
\hline $\begin{array}{l}\text { North Kalimantan: Mt. Leputung, north of Long } \\
\text { Bawan, Krayan }\end{array}$ & Indonesia & $900-1375$ & 09/07/1981 & B8069 & Preserved specimen \\
\hline $\begin{array}{l}\text { North Kalimantan: route from Pa Raya to SinarBaru, } \\
\text { North of Long Bawan, Krayan }\end{array}$ & Indonesia & 1150 & $17 / 07 / 1981$ & B9088 & Preserved specimen \\
\hline $\begin{array}{l}\text { North Kalimantan: South foot of Mt. Batu Linanit, } \\
\text { North of Long Bawan, Krayan }\end{array}$ & Indonesia & 1100 & $31 / 07 / 1981$ & B10342 & Preserved specimen \\
\hline $\begin{array}{l}\text { North Kalimantan: near Pa Nado, West to Long Bawan, } \\
\text { Krayan }\end{array}$ & Indonesia & $\begin{array}{l}1000- \\
1200\end{array}$ & $16 / 07 / 1981$ & B8553 & Preserved specimen \\
\hline $\begin{array}{l}\text { North Kalimantan: Mt. BatuHarun, North of Long } \\
\text { Bawan, Krayan }\end{array}$ & Indonesia & $\begin{array}{l}1150- \\
1650\end{array}$ & 25/07/1981 & B9858 & Preserved specimen \\
\hline $\begin{array}{l}\text { North Kalimantan: Mt. Paris, South of Long Bawan, } \\
\text { Krayan }\end{array}$ & Indonesia & $900-1050$ & 06/07/1981 & B7384 & Preserved specimen \\
\hline $\begin{array}{l}\text { North Kalimantan: Sinar Baru, North of Long Bawan, } \\
\text { Krayan }\end{array}$ & Indonesia & 1150 & 04/08/1981 & B10604 & Preserved specimen \\
\hline $\begin{array}{l}\text { North Kalimantan: Mt. Buduk Rian, South of Long } \\
\text { Bawan, Krayan }\end{array}$ & Indonesia & $900-1500$ & $18 / 08 / 1981$ & B11425 & Preserved specimen \\
\hline $\begin{array}{l}\text { North Kalimantan: Mt. Buduk Rakik, North of Long } \\
\text { Bawan, Krayan }\end{array}$ & Indonesia & $\begin{array}{l}1100- \\
1300\end{array}$ & $12 / 08 / 1981$ & B11339 & Preserved specimen \\
\hline Sumatera Utara: Aek Hotang, Merek, Karo & Indonesia & $1740-1770$ & - & - & $\begin{array}{l}\text { (Praptosuwiryo et al. } \\
\text { 2011) }\end{array}$ \\
\hline $\begin{array}{l}\text { Bengkulu: Bukit Daun Mas, Kayu Manis, Selupu } \\
\text { Rejang, Rejang Lebong }\end{array}$ & Indonesia & - & - & - & $\begin{array}{l}\text { (Praptosuwiryo and } \\
\text { Wardani 2008) }\end{array}$ \\
\hline Sabah: Mt. Kinabalu, eastern shoulder & Malaysia & 762 & 26/07/1961 & 998 & Preserved specimen \\
\hline Sabah: Mt. Kinabalu, near Park Headquarters & Malaysia & 1500 & 07/11/1980 & 9059 & Preserved specimen \\
\hline Sabah: Kota Kinabalu, Mile 31 Tamparuli Ranau road & Malaysia & 1400 & 06/06/1975 & SAN81653 & Preserved specimen \\
\hline Sabah: Ranau District, Kinabalu above hot springs & Malaysia & $914-1219$ & $18 / 02 / 1961$ & SAN24059 & Preserved specimen \\
\hline Sabah: Mt. Kinabalu, Penataran Basin & Malaysia & 1676 & 26/07/1933 & 34137 & Preserved specimen \\
\hline Sabah: Mt. Kinabalu, Gurulau & Malaysia & 1615 & $04 / 12 / 1933$ & 50709 & Preserved specimen \\
\hline Sabah: Mt. Kinabalu, Dallas & Malaysia & 914 & 02/04/1932 & 29162 & Preserved specimen \\
\hline Sabah: Mt. Kinabalu, Tenompok vicinity & Malaysia & 2134 & 08/06/1932 & 29672 & Preserved specimen \\
\hline Sabah: Mt. Kinabalu & Malaysia & - & 00/00/1931 & 26852 & Preserved specimen \\
\hline $\begin{array}{l}\text { Sabah: Mount Kinalabu, B.N. Borneo, Upper Kinabalu, } \\
\text { jungle ridge, Dahobang R. }\end{array}$ & Malaysia & - & $01 / 03 / 1933$ & 31697 & Preserved specimen \\
\hline $\begin{array}{l}\text { Sabah: Mount Kinabalu, Upper Kinabalu, Colombon R. } \\
\text { nr. rock wall }\end{array}$ & Malaysia & 2438 & 28/06/1933 & 33751 & Preserved specimen \\
\hline $\begin{array}{l}\text { Sabah: Mount Kinabalu, B.N. Borneo, Upper Kinabalu, } \\
\text { Dallas-Tinompok Spur, Top of jungle ridge }\end{array}$ & Malaysia & 1387 & $31 / 12 / 1931$ & 27740 & Preserved specimen \\
\hline Sabah: Mount Kinabalu, Kiau & Malaysia & - & $31 / 10 / 1915$ & 1520 & Preserved specimen \\
\hline Sabah: Mount Kinabalu, Kiau & Malaysia & - & $31 / 10 / 1915$ & 1514 & Preserved specimen \\
\hline $\begin{array}{l}\text { Sabah: Mt. Kinabalu, between Kamborangau, Pakka } \\
\text { Cave }\end{array}$ & Malaysia & 2926 & - & 3248 & Preserved specimen \\
\hline Sabah: Kinabalu National Park & Malaysia & 1759 & 08/03/2016 & 491452 & Preserved specimen \\
\hline Sabah: Kinabalu, Gurulau Spur & Malaysia & 1524 & $1910-02-00$ & 3999 & Preserved specimen \\
\hline Sabah: Tongod & Malaysia & - & $09 / 11 / 1931$ & 25378 & Preserved specimen \\
\hline Sabah: Batu Putih, District Kota Kinabatangan & Malaysia & 300 & 22/09/1991 & 132464 & Preserved specimen \\
\hline $\begin{array}{l}\text { Sabah: Kg. Melangkap Tomis. Hutan Simpan } \\
\text { Melangkap Tomis }\end{array}$ & Malaysia & 354 & 08/05/1996 & 2085 & Preserved specimen \\
\hline $\begin{array}{l}\text { Sabah: Kota Belud District, E of Melangkap Kappa on } \\
\text { NW side of Mt. Kinabalu. }\end{array}$ & Malaysia & $700-1000$ & 06/03/1984 & 3077478 & Preserved specimen \\
\hline $\begin{array}{l}\text { Sarawak: Gunong Mulu National Park, NW ridge of } \\
\text { Gunong Mulu. }\end{array}$ & Malaysia & 1700 & $30 / 06 / 1978$ & 6775 & Preserved specimen \\
\hline $\begin{array}{l}\text { Sarawak: Gunong Mulu National Park, W ridge of } \\
\text { Gunong Mulu near Camp } 4 \text { helipad. }\end{array}$ & Malaysia & 1800 & $29 / 06 / 1978$ & 6766 & Preserved specimen \\
\hline $\begin{array}{l}\text { Sarawak: Gunong Mulu National Park: W ridge of } \\
\text { Gunong Mulu near Camp } 2^{1 / 2} \text {. }\end{array}$ & Malaysia & 900 & 03/10/1976 & 13236 & Preserved specimen \\
\hline Sarawak: Gunong Mulu National Park & Malaysia & - & 03/10/1976 & 13230 & Preserved specimen \\
\hline Sarawak: Dulit Ridge & Malaysia & 1150 & $14 / 09 / 1932$ & 1797 & Preserved specimen \\
\hline Sarawak: Mt Dulit & Malaysia & 1463 & - & $13 / 2 ?$ & Preserved specimen \\
\hline Sarawak: Bario, Kelabit & Malaysia & 1110 & - & - & (Jaman et al. 1999) \\
\hline
\end{tabular}




\section{RESULTS AND DISCUSSION}

The value of open access species occurrence database

As an open-access species occurrence database, GBIF is a valuable source of where and when species have been recorded. Currently, the database contains more than 1.4 billion records -including more than 286 million of plant occurrences- and has contributed to the publication of 4,362 peer reviewed papers that used its occurrence data (GBIF.org 2020b). In term of Red List assessment, GBIF has served as the data source for extinction risk assessment of several taxa, such as spiders (Shirey et al. 2019), reptiles (Tolley et al. 2019), aloes (Rakotoarisoa et al. 2014) and timber trees (Mark 2018). In the present study, we have shown the advantage of using species occurrence data recorded in GBIF to assess the conservation status of $C$. arachnoideum. Compared to Praptosuwiryo (2020) as the case study in our paper, the number of occurrence records stored in GBIF is more than three times of that in Praptosuwiryo (2020) who mainly used data from Herbarium Bogoriense. The use of GBIF records in Red List assessment, however, has to be performed carefully as the data might have errors in the geographic coordinates (Zizka et al. 2020). Therefore, cleaning the data is necessary before mapping the occurrence points and conducting the assessment.

\section{EOO, AOO, and number of locations}

Using 41 occurrence records, the EOO and AOO of $C$. arachnoideum calculated by GeoCAT were 1,344,017.173 $\mathrm{km}^{2}$ and $156 \mathrm{~km}^{2}$, respectively (Figure 1). These values were much higher compared to the respected EOO and AOO values of calculated by Praptosuwiryo (2020) (i.e. $875,948.11 \mathrm{~km}^{2}$ and $44 \mathrm{~km}^{2}$, respectively). While the additional 2 occurrences of Gunung Rajabasa (Lampung) and Batu Putih (Sabah) significantly increased the EOO, the other 29 additional occurrences altogether increased the AOO of the species more than three times larger than that calculated by Praptosuwiryo (2020).

Praptosuwiryo (2020) stated that over-harvesting and habitat conversion are two main threats for $C$. arachnoideum. As the species grows in areas of high elevation, up to 2,134 m above sea level (Table 1), which has a low rate of habitat conversion, overharvesting is more likely to be the most serious plausible threat for $C$. arachnoideum. IUCN Standards and Petitions Committee (2019) stated that whenever collecting or harvest is identified as the most serious plausible threat, a location may be defined by the level of accessibility of collectors reaching harvestable areas. Using this definition, the number of locations for $C$. arachnoideum was estimated to be ranged from a minimum of 11 locations (number of distinguishable occurrence points in Figure 1) to a maximum of 41 locations (maximum number of occurrence points). These numbers are much higher than the 5 locations estimated by Praptosuwiryo (2020).

\section{Conservation status reassessment of Cibotium arachnoideum}

Praptosuwiryo (2020) considered the conservation status of $C$. arachnoideum as Endangered (EN) B2ab(i,ii,iii); C2a(ii). The present study, however, suggests that the species is not qualified for EN category under the criterion $B$ since the sub-criterion (a), i.e. number of locations threshold, was not met. Instead, $C$. arachnoideum would be qualified as Near Threatened (NT) category under the criterion B2ab(i,ii,iii). Although the species had an AOO that met the EN threshold, its number of locations (i.e. 11-41 locations) was higher than the threshold of the Vulnerable (VU) category (less than 10 locations).

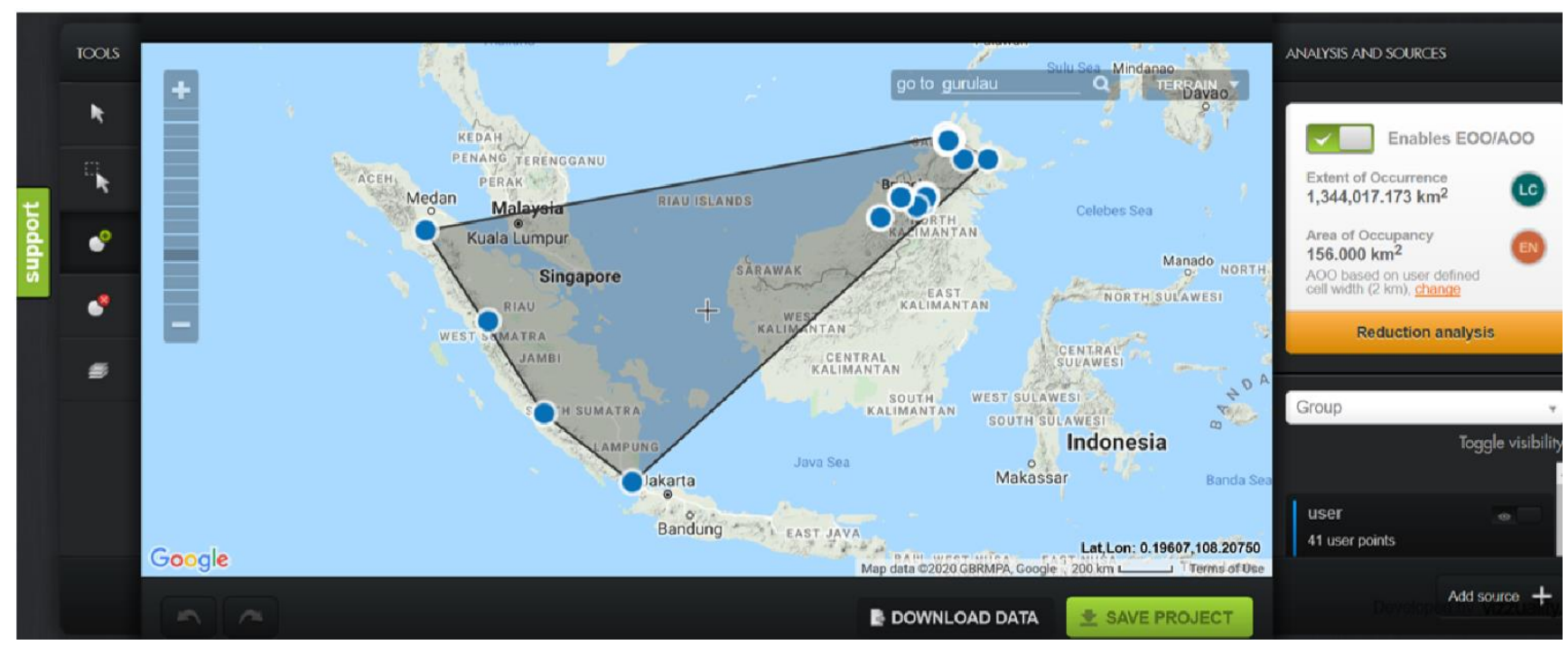

Figure 1. Extent of occurrence (EOO) and area of occupancy (AOO) of Cibotium arachnoideum analyzed using Geospatial Conservation Assessment Tool (GeoCAT) website (http://geocat.kew.org/) 
Criterion C2a(ii) was also used by Praptosuwiryo (2020) when assigning EN category for $C$. arachnoideum. It means that the author assumed there are less than 2,500 mature individuals of the species (criterion $\mathrm{C} 2$ ), of which 95-100\% are found in one subpopulation (sub-criterion a(ii)). While the assumption of total number of mature individuals is likely to be true, the estimation of $95-100 \%$ of mature individuals in one subpopulation was apparently misleading. The author stated that there are two subpopulations in Sumatra with population size of 372 and 19 individuals, and are nine subpopulations in Borneo with unknown population size. No information on population in Bornean subpopulations size does not mean that there are no mature individuals. In our view, the number of mature individuals in Borneo can be estimated roughly using species information from Sumatra. If we calculated total population size of the nine subpopulations in Borneo using lower estimation (19 individuals/subpopulation as in Sumatra), there are around 171 mature individuals in Borneo. Holttum (1963) stated that this species was abundant in Mount Kinabalu, Sabah, in secondary forests and survive burning for land clearing. Although land degradation in Borneo is carried out at very worrying pace (Bryan et al. 2013), mostly for logging and agricultural fields, populations at higher altitudes might survive as such habitat usually is less appealing to be worked. In the case of harvesting/exploitation, the Sumatran subpopulations of C. arachnoideum are treated similarly to $C$. barometz in which both species are used locally for medicinal purposes. Based on our literature reviews, C. arachnoideum is hardly discussed in Sabah medicinal plant (Bakar et al. 2018; Kulip 1997; Ahmad and Holdsworth 2003). For this reason, we may assume that the subpopulations in Borneo with their mature individuals would not be trifling. Therefore, the sub-criterion a(ii) that requires $95-100 \%$ of mature individuals to be in one subpopulation was not met. The estimation of population size would be much higher if the calculation used the number of locations identified by the present study.

Based on the results of present study, we propose the category of Vulnerable (VU) under criterion C2a(i) for the global conservation status of $C$. arachnoideum. The population size is estimated to be less than 10,000 individuals (C2) with continuing population decline primarily caused by overharvesting in Sumatra. In addition, a maximum of 1000 mature individuals is expected to be found in each subpopulation. Under this category, we argue that $C$. arachnoideum is not in a high risk of extinction in immediate terms (i.e. Endangered or Critically Endangered) which requires drastic measures in conservation efforts, such as forbidding exploitation or creating protected areas. Instead, the species is considered to face a high risk of extinction in the wild in the mediumterm future (i.e. Vulnerable). Advanced harvest control and encourage locals to shift wild harvest activity into, for instance, artificial propagation attempts might become realistic approach to reduce pressure.

\section{Suitable habitat of Cibotium arachnoideum}

Suitable habitats for $C$. arachnoideum were predicted with high success rate by MaxEnt. The average AUC of the model was $0.94 \pm 0.109$. Analysis of variable contribution showed that elevation had the highest effect on the distribution of the species with $52.52 \pm 1.97 \%$ contribution, followed by slope with a contribution of $10.5 \pm 2.53 \%$. Other environmental variables had contribution of less than $10 \%$ (Table 2).

The model suggests that the presence probability of $C$. arachnoideum increases with the increasing elevation and slope (Figure 2). According to the response curves, the species has a high probability of presence in areas with elevation of more than $1500 \mathrm{~m}$ asl with slope of more than $15^{\circ}$. This showed that the species preferred high altitudes and sloping habitats, which had relatively low possibility of being converted into settlements and agricultural fields. The results are in accordance with our previous statement that habitat conversion is unlikely to be a serious threat to C. arachnoideum. Therefore, for the Red List assessment of the species, number of populations has to be defined based on harvest being the most serious plausible threat, as is the case in our present study.

Table 2. Variables used in MaxEnt and their contribution to the suitable habitats prediction of Cibotium arachnoideum. Contribution values shown are the average \pm standard deviation over 20 replicate runs.

\begin{tabular}{lll}
\hline Variable & \multicolumn{1}{c}{ Description } & $\begin{array}{l}\text { \% } \\
\text { Contribution }\end{array}$ \\
\hline Aspect & Aspect in degrees & $0.96 \pm 0.46$ \\
Elevation & Elevation in meter & $52.52 \pm 1.97$ \\
Land cover & Land cover type & $3.6 \pm 0.56$ \\
Slope & Slope in degrees & $10.5 \pm 2.53$ \\
Bio1 & Annual mean temperature & $0.19 \pm 0.48$ \\
Bio2 & Mean diurnal range (mean of monthly & $8.84 \pm 2.18$ \\
& (max temp - min temp)) & \\
Bio3 & Isothermality (Bio2/Bio7) (×100) & $0.02 \pm 0.01$ \\
Bio4 & Temperature seasonality (standard & $0.0266 \pm$ \\
& deviation $\times 100)$ & 0.05 \\
Bio5 & Maximum temperature of warmest month & $0.2 \pm 0.48$ \\
Bio6 & Minimum temperature of coldest month & $0.09 \pm 0.08$ \\
Bio7 & Temperature annual range (Bio5-Bio6) & $1.87 \pm 1.3$ \\
Bio8 & Mean temperature of wettest quarter & $0.48 \pm 0.84$ \\
Bio9 & Mean temperature of driest quarter & $0.44 \pm 0.82$ \\
Bio10 & Mean temperature of warmest quarter & $0.33 \pm 0.85$ \\
Bio11 & Mean temperature of coldest quarter & $0.09 \pm 0.35$ \\
Bio12 & Annual precipitation & $1.3 \pm 0.36$ \\
Bio13 & Precipitation of wettest month & $0.95 \pm 0.29$ \\
Bio14 & Precipitation of driest month & $0.6 \pm 0.3$ \\
Bio15 & Precipitation seasonality (coefficient of & $2.04 \pm 0.38$ \\
& variation) & \\
Bio16 & Precipitation of wettest quarter & $9.75 \pm 1.47$ \\
Bio17 & Precipitation of driest quarter & $0.28 \pm 0.22$ \\
Bio18 & Precipitation of warmest quarter & $0.6 \pm 0.47$ \\
Bio19 & Precipitation of coldest quarter & $5.03 \pm 0.78$ \\
\hline & &
\end{tabular}




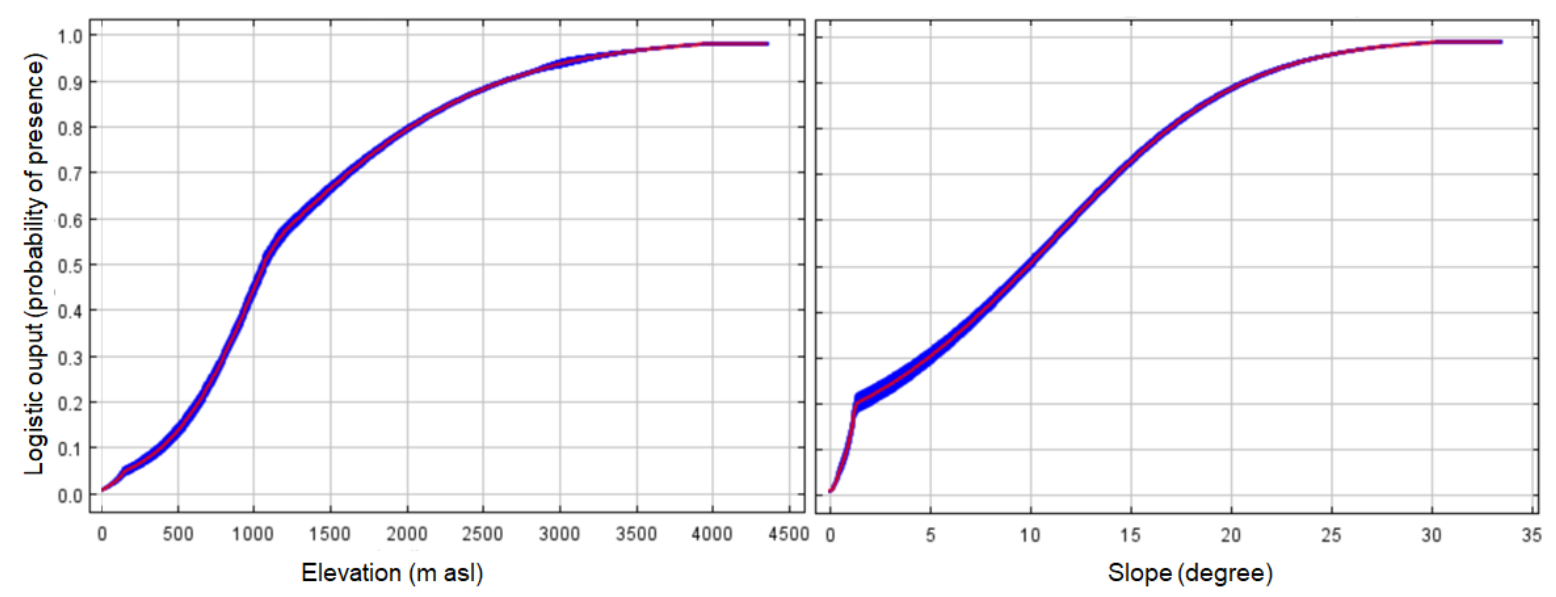

Figure 2. Response curves showing the relationships between elevation and slope with the probability of presence of Cibotium arachnoideum. Values shown are average over 20 replicate runs; blue margins show \pm 1 SD calculated over 20 replicates

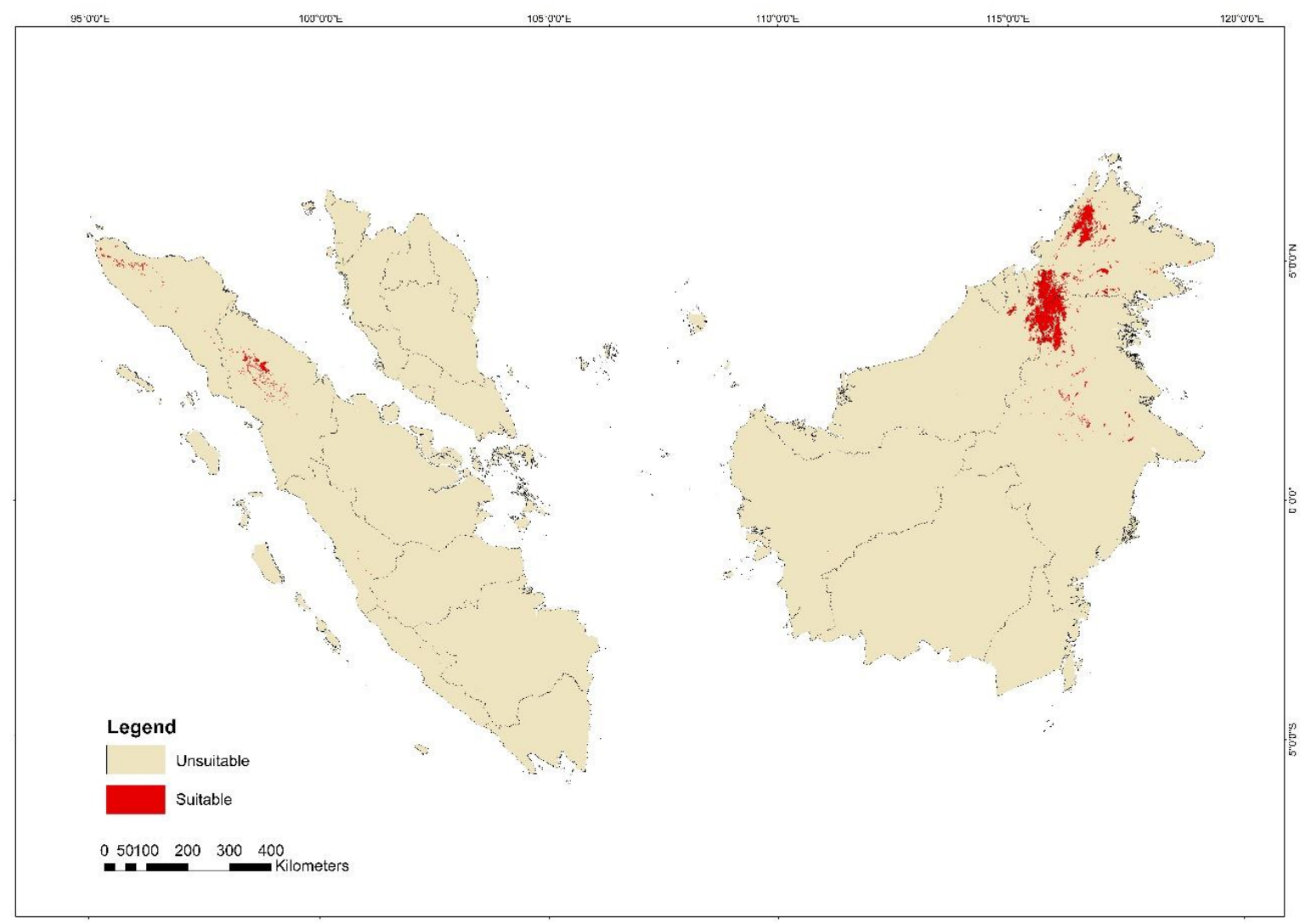

Figure 3. Predicted suitable habitats for Cibotium arachnoideum in Sumatra, Peninsular Malaysia, and Borneo

Most of the predicted suitable habitats of $C$. arachnoideum are located in Borneo (Figure 3). The largest suitable area is located in the mountain ranges between Sabah, Sarawak, and North Kalimantan, followed by Crocker Range in Sabah. Smaller and fragmented suitable habitats were also found in central North Kalimantan and southern Sabah. In Sumatra, suitable habitats of $C$. arachnoideum are concentrated in mountainous areas around Toba Lake and northern Aceh. Very small suitable habitats are also predicted to be present along the Bukit Barisan Range in the Province of West Sumatra, Jambi, Bengkulu, South Sumatra, and Lampung. These results are in opposition to the claim of Praptosuwiryo (2020) that at least $95 \%$ of mature individuals of $C$. arachnoideum were in one subpopulation. The claim was made by Praptosuwiryo (2020) based only on the recorded number of 372 and 19 mature individuals in North Sumatra and Bengkulu, respectively, without considering the 
subpopulations in Borneo. Instead, our analysis demonstrates that Borneo might retain a higher population size of $C$. arachnoideum compared to Sumatra.

In conclusion, using occurrence data from GBIF and peer-reviewed scientific papers, our study showed that $C$. arachnoideum has a larger EOO and $\mathrm{AOO}$, more number of locations and different conservation status compared to those in Praptosuwiryo (2020). These results were supported by the predicted suitable habitat map of $C$. arachnoideum produced by MaxEnt modelling method. As such, we propose the category of VU C2a(i) as the global conservation status for $C$. arachnoideum. Our study implies the advantage of using open access databases to increase the accuracy of extinction risk assessment under the IUCN Red List criteria in regions like Indonesia, where adequate information is not always readily available. To use these occurrence records, data cleaning is an essential first step as the data might contain errors in the geographic coordinates. While manual data cleaning based on expert knowledge is feasible on small taxonomic or geographic areas, automated flagging methods can be used for a huge dataset of occurrence records (Zizka et al. 2020).

\section{ACKNOWLEDGEMENTS}

We would like to thanks the anonymous reviewers for their valuable comments and suggestions to the manuscript.

\section{REFERENCES}

Ahmad FB, Holdsworth DK. 2003. Medicinal Plant of Sabah, East Malaysia - Part I. Pharmaceut Biol 41 (5): 340-346

Bachman S, Moat J, Hill AW, De La Torre J, Scott B. 2011. Supporting Red List threat assessments with GeoCAT: geospatial conservation assessment tool. ZooKeys 150: 117-126.

Bakar FIA, Bakar MFA, Abdullah N, Endrini S, Rahmat, A. 2018. A Review of Malaysian Medicinal Plant with Potentia AntiInflammatory Activity. Adv Pharm Sci 2018: 8603602. DOI: $10.1155 / 2018 / 8603602$.

Brites-Neto J, Duarte, KM. 2015. Modeling of spatial distribution for scorpions of medical importance in the São Paulo State, Brazil. Vet World 8 (7): 823-830.

Broxton PD, Zeng X, Sulla-Menashe D, Troch PA. 2014. A global land cover climatology using MODIS Data. J Appl Meteor Climatol 53: 1593-1605.

Bryan JE, Shearman PL, Asner GP, Knapp DE, Aoro G, Lokes B. 2013. Extreme Differences in Forest Degradation in Borneo: Comparing Practices in Sarawak, Sabah and Brunei. PLoS One 8 (7): e69679. DOI: 10.1371/journal.pone.0069679.

Elith J, Graham CH, Anderson RP, Dudík M, Ferrier S, Guisan A, Hijmans RJ, Huettmann F, Leathwick JR, Lehmann A, Li J, Lohmann LJ, Loiselle BA, Manion G, Moritz C, Nakamura M, Nakazawa Y, Overton JMcCM, Peterson AT, Phillips SJ, Richardson K, Scachetti-Pereira R, Schapire RE, Soberón J, Williams S, Wisz MS, Zimmermann NE. 2006. Novel methods improve prediction of species' distributions from occurrence data. Ecography 29 (2): 129151.

Elith J, Phillips SJ, Hastie T, Dudík M, Chee YE, Yates CJ. 2011. A statistical explanation of MaxEnt for ecologists. Divers Distrib 17 (1): 43-57.

GBIF.org. 2020a. GBIF Occurrence Download. DOI: 10.15468/dl.sixkab. Accessed: 6 April 2020.

GBIF.org. 2020b. GBIF Home Page. https://www.gbif.org. Accessed: 6 April 2020.
Hijmans RJ, Cameron SE, Parra JL, Jones PG, Jarvis A. 2005. Very high resolution interpolated climate surfaces for global land areas. Intl $\mathrm{J}$ Climatol 25 (15): 1965-1978.

Holttum RE. 1963. Cyatheaceae. Flora Malesiana Ser II 1 (2): 65-176.

IUCN. 2012. IUCN Red List categories and criteria, version 3.1, 2nd ed. IUCN, Gland and Cambridge.

IUCN. 2020. IUCN 2020. The IUCN Red List of Threatened Species. Version 2020-1. https://www.iucnredlist.org. Accessed: 5 April 2020.

IUCN Standards and Petitions Committee. 2019. Guidelines for Using the IUCN Red List Categories and Criteria. Version 14. Standards and Petitions Committee of the IUCN Species Survival Commission. http://www.iucnredlist.org/documents/RedListGuidelines.pdf. [6 April 2020].

Jaman R, Mat-Salleh K, Latiff A. 1999. Provisional account and checklist of Ferns and Fern-Allies in Bario, Kelabit Highlands, Sarawak. ASEAN Review of Biodiversity and Environmental Conservation (ARBEC), 1-12. http://www.arbec.com.my/pdf/art3julaug99.pdf.

Kulip J. 1997. A preliminary Survey of Traditional Medicinal Plant in the West Coast and Interior of Sabah. J Trop For Sci 10 (2): 271-274

Kumar S, Stohlgren TJ. 2009. Maxent modeling for predicting suitable habitat for threatened and endangered tree Canacomyrica monticola in New Caledonia. J Ecol Nat Environ1: 94-98.

Liu C, Newell G, White M. 2016. On the selection of thresholds for predicting species occurrence with presence-only data. Ecol Evol 6 (1): 337-348.

Mark J. 2018. Applications of the IUCN Red List in evaluating global extinction risk of timber tree species. [Dissertation]. Bournemouth University, Dorset, UK.

Pearson RG, Raxworthy CJ, Nakamura M, Peterson AT. 2007. Predicting species distributions from small numbers of occurrence records: a test case using cryptic geckos in Madagascar. J Biogeogr 34 (1): 102-117.

Phillips SJ, Anderson RP, Schapire RE. 2006. Maximum entropy modeling of species geographic distributions. Ecol Model 190 (3-4): 231-259. Praptosuwiryo TN. 2020. Assessing the conservation status of tree fern Cibotium arachnoideum (C. Chr.) Holttum. Biodiversitas 21: 1379-1384.

Praptosuwiryo TN. 2020. Assessing the conservation status of tree fern Cibotium arachnoideum (C.Chr.) Holttum. Biodiversitas 21: 13791384.

Praptosuwiryo TN, Pribadi DO, Puspitaningtyas DM, Hartini S. 2011. Inventorying the tree fern Genus Cibotium of Sumatra: Ecology, population size and distribution in North Sumatra. Biodiversitas 12: 204-211.

Praptosuwiryo TN, Wardani W. 2008. Survei Cibotium barometz Bengkulu IV: Studi potensi, variasi morfologi dan monitoring regenerasinya secara vegetatif. Laporan Teknis. Bidang Botani, Pusat Penelitian Biologi, LIPI, Bogor. [Indonesian]

Rakotoarisoa SE, Klopper RR, Smith GF. 2014. A preliminary assessment of the conservation status of the genus Aloe L. in Madagascar. Bradleya32: 81-91.

Rodrigues AS, Pilgrim JD, Lamoreux JF, Hoffmann M, Brooks TM. 2006. The value of the IUCN Red List for conservation. Trends Ecol Evol 21: 71-76.

Shirey V, Seppälä S, Branco VV, Cardoso P. 2019. Current GBIF occurrence data demonstrates both promise and limitations for potential red listing of spiders. Biodiv Data J 7: e47369. DOI: 10.3897/BDJ.7.e47369.

Tolley KA, Alexander GJ, Branch WR, Bowles P, Maritz B. 2019. Conservation status and threats for African reptiles. Biol Conserv 204: 63-71.

Wei B, Wang R, Hou K, Wang X, Wu W. 2018. Predicting the current and future cultivation regions of Carthamus tinctorius L. using MaxEnt model under climate change in China. Glob Ecol Conserv 16: e00477. DOI: 10.1016/j.gecco.2018.e00477.

Wisz MS, Hijmans RJ, Li J, Peterson AT, Graham CH, Guisan A, NCEAS Predicting Species Distributions Working Group. 2008. Effects of sample size on the performance of species distribution models. Divers Distrib 14 (5): 763-773.

Zizka A, Carvalho FA, Calvente A, Baez-Lizarazo MR, Cabral A, Coelho JFR, Colli-Silva M, Fantinati MR, Fernandes MF, Ferreira-Araujo T, Moreira FGL. 2020. No one-size-fits-all solution to clean GBIF. bioRxiv. DOI: 10.1101/2020.03.12.974543. 